\title{
ACUTE RESPONSE TO ENDURANCE EXERCISE STRESS: FOCUS ON CATABOLIC/ANABOLIC INTERPLAY BETWEEN CORTISOL, TESTOSTERONE, AND SEX HORMONE BINDING GLOBULIN IN PROFESSIONAL ATHLETES
}

\author{
AKUTNI ODGOVOR TOKOM TRENINGA IZDRŽLIVOSTI: FOKUS NA UZAJAMNO \\ KATABOLIČKO/ANABOLIČKO DEJSTVO KORTIZOLA, TESTOSTERONA I VEZUJUĆEG \\ GLOBULINA SEKSUALNIH HORMONA I ADAPTACIJU KOD PROFESIONALNIH SPORTISTA
}

\author{
Bojana Popovic ${ }^{1}$, Dejana Popovic ${ }^{2}$, Djuro Macut ${ }^{1}$, Ivana Bozic Antic ${ }^{1}$, Tatjana Isailovic ${ }^{1}$, \\ Sanja Ognjanovic ${ }^{1}$, Tamara Bogavac ${ }^{1}$, Valentina Elezovic Kovacevic ${ }^{1}$, Dusan Ilic ${ }^{1}$, \\ Mirjana Petrovic ${ }^{1}$, Svetozar Damjanovic ${ }^{1}$ \\ ${ }^{1}$ Clinic for Endocrinology, Diabetes and Metabolic Diseases, Clinical Centre of Serbia, Belgrade, Serbia \\ ${ }^{2}$ Clinic for Cardiology, Clinical Centre of Serbia, Belgrade, Serbia
}

\begin{abstract}
Summary
Background: Endocrine system plays a major role in both permissive and regulatory activities in order to adequately respond to physical stress of exercise. But level and direction of activation depend on many factors and are not easily interpreted.

Methods: We tested a group of male professional athletes (21 water polo players and 15 wrestlers), together with 20 sedentary controls matched by age. All participants took a continuous progressive exercise stress test on a treadmill until exhaustion and plateau of oxygen consumption $\left(\mathrm{VO}_{2}\right)$. Blood samples for cortisol, sex hormone binding globulin (SHBG) and testosterone were drawn in four time points: baseline (B), start of the test (S), point of maximal strain (MAX) and in the $3^{\text {rd }}$ minute of recovery period $(R)$. Results: Cortisol levels significantly increased in both groups, but the response between $S$ and MAX was more pronounced in controls $(p=0.036)$. The athletes had significantly higher levels of cortisol in all points in test, except during $R(p=0.118)$, when their cortisol levels gradually started to decline. Significant increase in total testosterone
\end{abstract}

\section{Kratak sadržaj}

Uvod: Endokrini sistem ima i permisivnu i regulatornu ulogu kako bi se adekvatno odgovorilo na fizički stress prouzrokovan vežbanjem. Ali nivo i smer aktivacije zavise od mnogih faktora i nisu jednostavni za interpretaciju.

Metode: Testirali smo grupu muških profesionalnih sportista (21 vaterpolista i 15 rvača), i 20 sedentarnih kontrola uparenih prema godinama. Sproveden je ergospirometrijski test do iscrpljenosti i platoa potrošnje kiseonika $\left(\mathrm{VO}_{2}\right)$. Uzorci krvi za određivanje kortizola, vezujućeg globulin seksualnih hormona (SHBG) i testosterona su uzimani tokom 4 vremena: bazno (B), na početku testa $(S)$, u maksimalnom naporu (MAX) i u 3. minutu oporavka (R). Rezultati: Nivo kortizola je značajno porastao u obe grupe, ali je odgovor između S i MAX bio naglašeniji kod kontrola $(p=0,036)$. Sportisti su imali značajno više vrednosti kortizola u svim tačkama testa, izuzev tokom $R(p=0,118)$, s obzirom da su njihove vrednosti kortizola počele da opadaju. Značajan porast vrednosti ukupnog testosterona je u velikoj meri bio posledica porasta nivoa SHBG ( $p<0,01$ za oba). Posledično, izračunate vrednosti slobodnog testo-

Address for correspondence:

Svetozar Damjanovic, MD, PhD

Clinic for Endocrinology, Diabetes and Metabolic Diseases

Clinical Centre of Serbia

Dr Subotica 13

11000 Belgrade, Serbia

Phone: +381113639741

Fax: +381112685357

e-mail: svetadamjanovic@gmail.com

List of abbreviations: CPET, cardiopulmonary exercise test on a treadmill (CPET); $\mathrm{VO}_{2}$, oxygen consumption; $\mathrm{VO} 2 \mathrm{max}$, maximal oxygen consumption; $B$, baseline; $S$, start of the test; $M A X$, point of maximal effort; $R$, the 3rd minute of recovery; RIA, radioimmuno assay; IRMA, immunoradiometric assay; SHBG, sex hormone binding globulin; FAl, free-androgen index; HPA axis, hipothalamo-pituitary-adrenal axis. 
was in great deal a consequence of increase in SHBG level ( $p<0.01$ for both). Consequently, calculated free testosterone significantly decreased during test $(p=0.008)$, and the drop was more pronounced in athletes. This was in concordance with significant correlation between SHBG and cortisol level demonstrated in athletes, but not in controls.

Conclusions: It seems that high intensity endurance exercise favors catabolic response, but the level of response highly depends on a previous level of training.

Keywords: endurance exercise, catabolic/anabolic, testosterone, sex hormone binding globulin

\section{Introduction}

Physical exercise represents a specific form of stress, engaging endocrine system at multiple levels, in order to provide necessary functional responses and aid in morphological adaptations. Normal endocrine function is essential not only for acute stress responses, but also for maintaining positive energy status, anabolic/catabolic balance, and body composition (1). Various neuroendocrine changes can occur in athletes, particularly in heavy exercisers, and are mostly physiologic and in response to a low energy state. These adaptive changes conserve energy for more important and vital functions (by suppression of hypothalamo-pituitary-gonadal axis and thyroid hormones), and increase substrate availability (by increases in cortisol and growth hormone both of which are gluconeogenic, as well as decreases in leptin and increases in ghrelin, which should stimulate caloric intake) (2). Additionally, from the aspect of muscle protein synthesis and degradation, testosterone and cortisol have long been studied as potential biomarkers for the catabolic and anabolic state of body (3). Still, few and conflicting data are available considering testosterone responses to exercise, and mostly regarding resistance exercise, and far less regarding male athletes compared to female. Cortisol responses have been studied more thoroughly, but with conflicting differences in interpretation due to non-standardized study designs. It was our aim to analyze cortisol and testosterone responses to endurance exercise under carefully designed circumstances.

\section{Materials and Methods}

This study was conducted in the Clinical Centre of Serbia, at the Clinic for Endocrinology, Diabetes and Metabolic Diseases, and the Clinic for Cardiology. Experimental design was approved by the local Ethical Committee, and each participant gave written informed consent. All procedures were carried out in conformance with the Declaration of Helsinki ethical guidelines.

Study group consisted of 36 professional athletes: 21 water-polo players (aged 21.38 \pm 3.54 sterona su značajno opadale tokom testa $(p=0,008)$, a pad je bio izraženiji kod sportista. Ovaj rezultat je u skladu sa demonstriranom značajnom korelacijom između SHBG i kortizola kod sportista, ali ne i kod kontrola.

Zaključak: Naši rezultati ukazuju da trening izdržljivosti visokog intenziteta favorizuje katabolički odgovor, ali nivo odgovora značajno zavisi od nivoa utreniranosti.

Ključne reči: trening izdržljivosti, kataboličko/anabolički odnos, testosteron, vezujući globulin seksualnih hormona

years), and 15 wrestlers (aged 23.25 \pm 3.53 ). The athletes trained at least 15 hours a week, and were examined during intensive training period (prior to competition season). Control group consisted of 20 male sedentary subjects matched by age $(21.35 \pm 2.01, p=0.121)$, engaged in sports only at recreational level. All participants were healthy nonsmokers.

\section{Experimental protocol}

All participants underwent progressive continuous cardiopulmonary exercise test on a treadmill (CPET), with assessment of oxygen consumption $\left(\mathrm{VO}_{2}\right)$. Test was carried out between $3.00-5.00$ p.m. since that period closely represented typical period during which the athletes trained. The protocol consisted of $3 \mathrm{~min}$ rest, $2 \mathrm{~min}$ at speed of $6 \mathrm{~km} / \mathrm{h}$ and $2 \%$ inclination, $2 \mathrm{~min}$ at speed $9 \mathrm{~km} / \mathrm{h}$ and $2 \%$ inclination, after that increasing inclination for $2 \%$ every 2 min until the criteria for maximal test were reached. The protocol was made by pretesting of 9 subjects randomly chosen, to optimize the duration of the test (8-12 $\mathrm{min})$. All the recommendations and criteria for maximal test are described elsewhere (4).

Blood sampling for cortisol, testosterone and SHBG (sex hormone binding globulin) was done at 4 time points: $B$ at baseline (during rest), $S$ at the start of the test (the moment of stepping on a treadmill), MAX at the point of maximal effort, and $R$ at the $3^{\text {rd }}$ minute of recovery.

\section{Hormone analyses}

Blood samples were collected through an indwelling venous catheter inserted in an arm vein, and $10 \mathrm{~mL}$ of blood were drawn for each sample. Initial blood samples were drawn $30 \mathrm{~min}$ after catheter insertion, and catheter patency was maintained with saline. Samples were centrifuged and the plasma was stored at $-80^{\circ} \mathrm{C}$ until assayed.

All plasma samples were analyzed in duplicate. Cortisol concentration was measured by means of radioimmuno assay - RIA (CORT-CT2, CIS bio inter- 
national, Gif-Sur-Yvette Cedex, France). Minimal detectible concentration was $4.6 \mathrm{nmol} / \mathrm{L}$; intra- and interassay coefficients of variation $(\mathrm{CV} \mathrm{s})$ were below $5.4 \%$ and $7.3 \%$, respectively. Testosterone was determined by RIA (TEST-C2, CIS Biolnternational, GifSur-Yvette Cedex, France) with minimal detectible concentration of $0.1 \mathrm{nmol} / \mathrm{L}$, and intra- and interassay CVs of $4.5 \%$ and $5.1 \%$ respectively. Sex-hormone binding globuline was detected by immunoradiometric assay - IRMA (SHBG-RIACT, CIS Biolnternational, Gif-Sur-Yvette Cedex, France), with minimal detectible concentration of $0.5 \mathrm{nmol} / \mathrm{L}$, and intra- and interassay $\mathrm{CV}$ s of 3.9 and $4.7 \%$ respectively. From the levels of testosterone and SHBG free androgen index (FAl) was calculated as a measure of free testosterone level, by using a formula $\mathrm{FAI}=($ testosterone $/ \mathrm{SHBG}) \times$ 100. Testosterone/cortisol ratio ( $\mathrm{T} / \mathrm{C})$ was calculated by using total testosterone value.

\section{Statistical analysis}

Statistical analysis was performed by SPSS software (SPPS for Windows, 21.0), and values of $\mathrm{p}<0.05$ were considered significant. After testing for normality of data, comparisons between variables were performed with Student's t-test/One-way ANOVA (for normally distributed), and MannWhitney/Kruskall-Wallace test (for non-normally distributed variables). One-way ANOVA for repeated measures was used to assess cortisol, testosterone, SHBG and FAl levels change during CPET. Prior to testing, non-normally distributed variables were logaritmically transformed in order to achieve normality. Within-Subjects effect was analyzed with Univariate tests, and a Geisser-Greenhouse correction was used when sphericity assumption was violated.

\section{Results}

Figure 1 demonstrates cortisol response during CPET. Overall increase in cortisol level was significant over time $\left(F_{1.54}=72.31, p<0.01\right)$, but the pattern of response was significantly different between athletes and controls $\left(F_{1.54}=3.81, p=0.036\right)$. The difference was significant between $S$ and $\operatorname{MAX}\left(\mathrm{F}_{1.0}=6.59\right.$, $p=0.013$ ) with response being more pronounced in controls, and between MAX and R $\left(F_{1.0}=4.74\right.$, $\mathrm{p}=0.034$ ) with cortisol slowly starting to decline in athletes, while it was still rising in controls. The athletes had higher cortisol levels starting from baseline to the point of maximal strain $(p=0.003, p=0.001$, and $p=0.045$ respectively for $B, S$ and $M A X)$, but the difference was lost during $R(p=0.118)$.

Total testosterone response was in great part influenced by acute response of SHBG. Both responses were significant over time $\left(F_{1,61}=51.67, p<0.01\right.$; and $\left.F_{1.91}=64.04, p<0.01\right)$, with similar pattern of response between groups $\left(F_{1.61}=1.70, p=0.193\right.$;

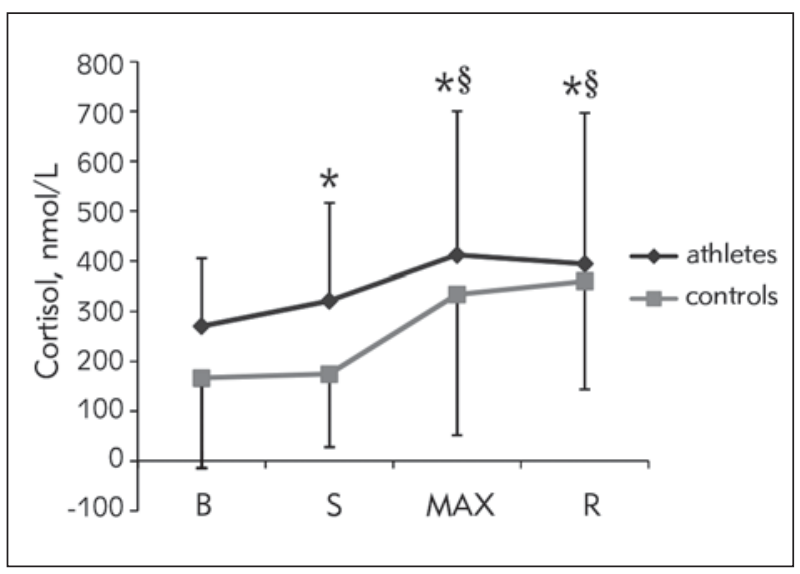

Figure 1 Cortisol response during CPET (data presented with actual values)

$B$, baseline; $S$, start of the test; MAX, point of maximal strain; $\mathrm{R}, 3$ rd minute of recovery; ${ }^{*}$, significant change compared to the previous time point; $\S$, significant difference in response between groups.

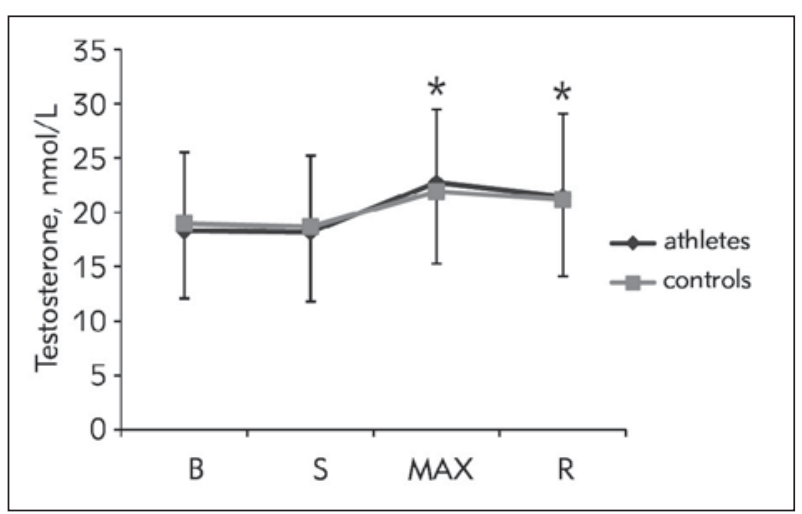

Figure 2 Total testosterone response during CPET (data presented with actual values)

$B$, baseline; $S$, start of the test; MAX, point of maximal strain; $\mathrm{R}, 3$ rd minute of recovery; ${ }^{*}$, significant change compared to the previous time point.

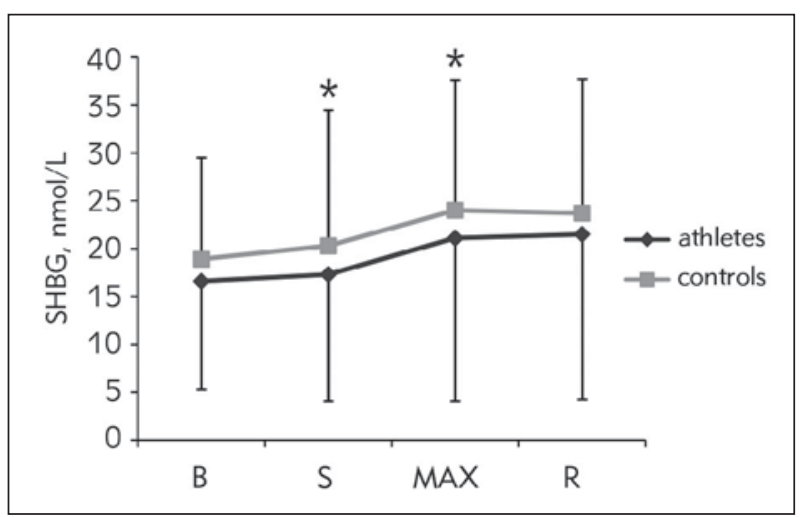

Figure 3 SHBG response during CPET (data presented with actual values)

$B$, baseline; $S$, start of the test; MAX, point of maximal strain; $\mathrm{R}, 3$ rd minute of recovery; ${ }^{*}$, significant change compared to the previous time point. 
Table I Correlations between SHBG and cortisol values throughout the CPET.

\begin{tabular}{|c|l|c|c|c|c|c|c|c|c|}
\hline & & 1 & 2 & 3 & 4 & 5 & 6 & 7 & 8 \\
\hline 1 & SHBG B & 1 & $0.971^{* *}$ & $0.909^{* *}$ & $0.941^{* *}$ & $0.521^{* *}$ & $0.594^{* *}$ & $0.504^{* *}$ & $0.517^{* *}$ \\
\hline 2 & SHBG S & & 1 & $0.914^{* *}$ & $0.947^{* *}$ & $0.450^{* *}$ & $0.551^{* *}$ & $0.500^{* *}$ & $0.522^{* *}$ \\
\hline 3 & SHBG MAX & & & 1 & $0.944^{* *}$ & $0.390^{*}$ & $0.463^{* *}$ & $0.359^{*}$ & $0.380^{*}$ \\
\hline 4 & SHBG R & & & & 1 & $0.445^{* *}$ & $0.486^{* *}$ & $0.420^{*}$ & $0.441^{* *}$ \\
\hline 5 & cortisol B & & & & & 1 & $0.744^{* *}$ & $0.542^{* *}$ & $0.485^{* *}$ \\
\hline 6 & cortisol S & & & & & & 1 & $0.850^{* *}$ & $0.789 * *$ \\
\hline 7 & cortisol MAX & & & & & & & 1 & $0.956 * *$ \\
\hline 8 & cortisol R & & & & & & & 1 \\
\hline
\end{tabular}

$\mathrm{B}$, baseline; $\mathrm{S}$, start of the test; MAX, point of maximal strain; $\mathrm{R}, 3$ rd minute of recovery; ${ }^{*}, \mathrm{p}<0.05 ;{ }^{* *}, \mathrm{p}<0.01$.

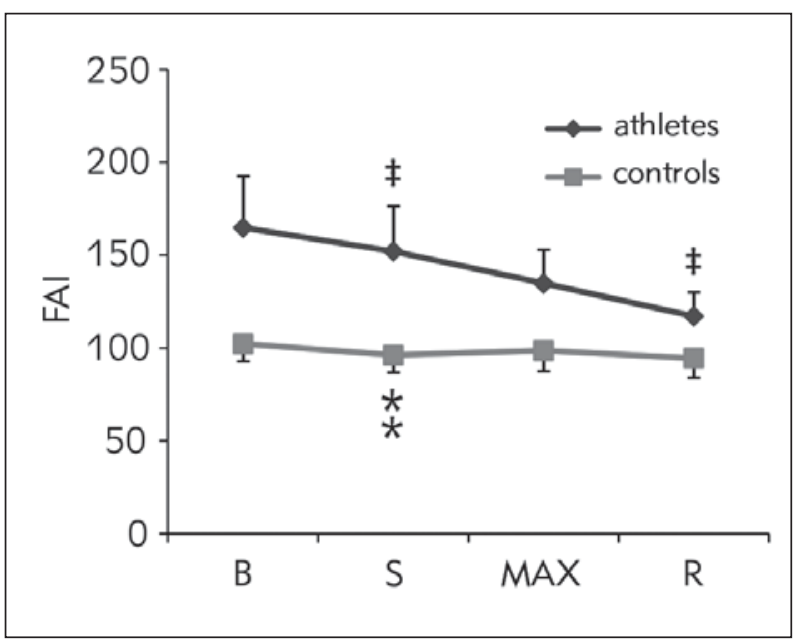

Figure 4 FAl response during CPET (data presented with actual values)

$B$, baseline; $S$, start of the test; MAX, point of maximal strain; $\mathrm{R}, 3$ rd minute of recovery; ; $\ddagger$, significant change compared to the previous time point in athletes; $*$, significant change compared to the previous time point in controls.

and $\left.F_{1.91}=2.37, p=0.143\right)$, and significant increase between $S$ and MAX $\left(F_{10}=86.80, p<0.001\right.$; and $\mathrm{F}_{1,0}=46.88, \mathrm{p}<0.001$ ) (Figures 2 and 3).

Unlike these, FAl levels significantly declined over time $\left(F_{1,65}=2.95, p=0.008\right)$, similarly in both groups $\left(F_{1,65}=0.580, p=0.530\right)$ (Figure 4). Significant decrease in athletes was confirmed between $B$ and $S\left(F_{1.0}=6.36, p=0.017\right)$, and between MAX and $R\left(F_{1,0}=11.35, p=0.002\right)$. The only change observed in controls was a decrease between $B$ and $S$ $\left(F_{1,0}=5.40, p=0.032\right)$, with stable values further on.

All values of SHBG significantly correlated with all cortisol levels in athletes (Table I), while no correlation was observed in controls (data not shown).

\section{Discussion}

Our results demonstrate that endurance exercise of sufficient intensity successfully activates neuroendocrine stress system. Cortisol significantly increased in all subjects, but specificities of cortisol response depended on previous level of training. Levels of FAI demonstrated steady decline all through the recovery period, but this was observed only in athletes.

As a catabolic hormone, cortisol increases availability of all fuel substrates for working muscles by mobilization of glucose, free fatty acids, and amino acids from endogenous stores (5). At the same time, cortisol maintains normal vascular integrity and responsiveness during exercise, and prevents overreaction of the immune system in the face of repeated exercise-induced muscle damage (6). The minimum intensity of endurance exercise necessary to produce cortisol response is about $60 \%$ of $\mathrm{VO}_{2}$ max. Afterwards, cortisol levels increase linearly with exercise intensity, and this threshold is independent of training (7). Greater cortisol response was observed in athletes currently in competition compared to non competitive athletes, with basal cortisol levels gradually increasing during preparatory period $(8,9)$. This indicates that high catabolic environment is essential tools for adaptation in high-stress situations with high fuel demand (9). With higher basal cortisol levels, our athletes in fact had a necessity for a smaller add up to achieve peak cortisol levels, required for a proper biological effect, and this might be one of forms of adaptation to repeated physical stress in athletes. There is an interesting observation that increased cortisol responses to exercise performed in the afternoon might be a consequence of diurnal variations of glycogen status of the individual, with peak values in the morning and nadir in the evening $(10,11)$. Morning exercise significantly impaired body's ability to maintain euglycemia during exercise later same day (12). Impaired cortisol response to exercise might be one of early signs of overreaching/overtraining. To the contrary, adequate cortisol response to challenge as 
well as high basal cortisol concentrations reflect good adaptation (13).

Various studies report different basal cortisol levels in athletes when compared to sedentary subjects (14). Higher basal cortisol levels demonstrated in our athletes might be a consequence of a particular time of day during which the experiment was conducted, and which closely resembled a period during which the athletes normally trained. Training rhythm of professional athletes, being more or less fixated to a particular part(s) of day, affects the normal circadian rhythm of cortisol secretion by leading to a phase shift in hipothalamo-pituitary-adrenal (HPA) axis activity (15). Additionally, one should bear in mind that chronic hypercortisolism is not induced by the stress of exercise itself, but by chronic energy deficiency (negative energy balance), as seen during prolonged periods of physical strain and especially in overreaching/overtraining (16). With this respect, it is also relevant if the athletes are tested during pre-competition, competition or out-of competition period of their season.

We observed changes in both testosterone and SHBG level, which demonstrates a change in availability of free testosterone during exercise. However, a drop during recovery period is not related to SHBG change, and reflects a drop of testosterone itself. It seems that in a state of chronic energy deficiency catabolic signal prevails, and antagonizes anabolic processes (17). An opposite response in total and free testosterone has been previously demonstrated in only a few studies, but there are no data on SHBG $(17,18)$.

Testosterone level very much depends on type, intensity and duration of exercise. Endurance athletes often exhibit lower testosterone concentrations than more explosive and resistance athletes (19-21). When comparing long-term effects of high-intensity and moderate-intensity training patterns, the number of hours of high-intensity exercise significantly negatively correlated with testosterone levels; these athletes also demonstrated worse semen parameters compared to moderately-trained athletes (22). Timing of analysis seems important as well, with the lowest testosterone levels verified during competition season compared to training and resting period of a season $(23,24)$. Testosterone has many functions crucially important for athletic performance. Aside from effect on behavior (behavior characteristics, aggression and cognitive processes), testosterone improves muscle protein synthesis/decreases muscle protein degradation, and stimulates bone formation/decreases bone resorption (25-27). All these anabolic effects require certain level of energy availability. Probably the most drastic example of this concept is a so-called »exercise-hypogonadal male condition ", characteristically observed in endurance athletes engaged in disciplines that require prolonged exercise activities, as a state of a long-term hypotestosteronemia coming out of chronic energy deficit $(28,29)$. It is also observed in sport disciplines where leanness is considered a competitive advantage (gymnastics, wrestling, running) (29).

The same principle applies for the acute responses to exercise. Resistance exercise generally, and endurance exercise with relatively short sessions, produce acute rise in testosterone level, probably due to effect of elevated catecholamines (30-34). On the contrary, more prolonged sessions, sessions of very high intensity, and sessions during period of intensive training, produce an acute decrease in testosterone level $(35,36)$. Negative correlation was demonstrated between cortisol and testosterone, suggesting a catabolic tendency under these circumstances (36). Both chronic energy deficit and direct suppressive effect of cortisol on testosterone secretion might be responsible for this effect (36).

\section{Conclusion}

Acute stress of intensive endurance exercise represents a strong stimulus for cortisol response. This response, in concert with absence of rise in testosterone, represents catabolic signal necessary to provide fuel availability. Parallel rise of cortisol and SHBG is in line with this demand.

\section{Conflict of interest statement}

The author stated that she has no conflicts of interest regarding the publication of this article. 


\section{References}

1. Mastorakos G, Pavlatou M, Diamanti-Kandarakis E, Chrousos GP. Exercise and the Stress System. Hormones (Athens) 2005; 4(2): 73-89.

2. Misra M. Neuroendocrine mechanisms in athletes. Handb Clin Neurol 2014; 124: 373-86.

3. Crewther B, Keogh J, Cronin J, et al. Possible stimuli for strength and power adaptation: acute hormonal responses. Sports Med 2006; 36(3): 215-38.

4. ATS/ACC/AHA Guideline Update for Exercise Testing: Summary Article. A Report of the American College of Cardiology / American Heart Association Task Force on Practice Guidelines (Committee to Update the 1997 Exercise Testing Guidelines). J Am Coll Cardiol 2002; 40(8): 1531-40.

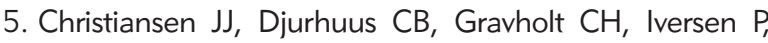
Christiansen JS, Schmitz $\mathrm{O}$, et al. Effects of cortisol on carbohydrate, lipid, and protein metabolism: studies of acute cortisol withdrawal in adrenocortical failure. J Clin Endocrinol Metab 2007; 92(9): 3553-9.

6. Milošević Georgiev A, Krajnović D, Kotur-Stevuljević J, Ignjatović S, Marinković V. Undiagnosed hyperglycaemia and hypertension as indicators of the various risk factors of future cardiovascular disease among population of Serbian students. J Med Biochem 2018; 37; 289-98.

7. Duclos $M$, Corcuff JB, Rashedi $M$, Fougère $V$, Manier $G$. Trained Versus Untrained Men: Different Immediate Post-Exercise Responses of Pituitary-Adrenal Axis. A preliminary Study. Eur J Appl Physiol 1997; 75: 343-50.

8. Paccotti P, Minetto M, Terzolo M, Ventura M, Ganzit GP, Borrione $P$, et al. Effects of high-intensity isokinetic exercise on salivary cortisol in athletes with different training schedules: relationships to serum cortisol and lactate. Int J Sports Med 2005; 26(9): 747-55.

9. Purge $P$, Jürimäe $J$, Jürimäe T. Hormonal and psychological adaptation in elite male rowers during prolonged training. J Sports Sci 2006; 24(10): 1075-82.

10. Meeusen R, Piacentini MF, Busschaert B, Buyse L, De Schutter G, Stray-Gundersen J (2004). Hormonal responses in athletes: the use of a two bout exercise protocol to detect subtle differences in (over)training status. Eur J Appl Physiol 2004; 91(2-3): 140-6.

11. Conlee RK, Rennie MJ, Winder WW. Skeletal muscle glycogen content: diurnal variation and effects of fasting. Am J Physiol 1976; 231(2): 614-18.

12. Galassetti P, Mann S, Tate D, Neill RA, Wasserman DH, Daviss SN. Effect of morning exercise on counteregulatory responses to subsequent, afternoon exercise. J Appl Physiol 2001; 91: 91-99.

13. Urhausen A, Kindermann W. Diagnosis of overtraining. What tools do we have? Sports Medicine 2002; 32: 95102.

14. Kraemer WJ, Ratamess NA. Hormonal Responses and Adaptations to Resistence Exercise and Training. Sports Med 2005; 35(4): 339-61.

15. Van Reeth O, Sturis J, Byrne MM, Blackman JD, L'Hermite-Balériaux $M$, Leproult $R$, et al. Nocturnal Exercise
Phase Delays Circadian Rhythms of Melatonin and Thyrotropin Secretion in Normal Men. Am J Physiol Endocrino Metab 1994; 266(29): E964-74.

16. Loucks $A B$, Thuma JR. Luteinizing hormone pulsatility is disrupted at a threshold of energy availability in regularly menstruating women. J Clin Endocrinol Metab 2003; 88(1): 297-311.

17. Daly W, Seegers CA, Rubin DA, Dobridge JD, Hackney AC. Relationship between stress hormones and testosterone with prolonged endurance exercise. Eur J Appl Physiol 2005; 93(4): 375-80.

18. Martínez AC, Seco Calvo J, Tur Marí JA, Abecia Inchaurregui LC, Orella EE, Biescas AP. Testosterone and cortisol changes in professional basketball players through a season competition. J Strength Cond Res 2010; 24(4): 1102-8.

19. Healy ML, Gibney J, Pentecost C, Wheeler MJ, Sonksen $\mathrm{PH}$. Endocrine profiles in 693 elite athletes in the postcompetition setting. Clin Endocrinol (Oxf) 2014; 81(2): 294-305.

20. Crewther BT, Cook C, Cardinale M, Weatherby RP, Lowe T. Two emerging concepts for elite athletes: the shortterm effects of testosterone and cortisol on the neuromuscular system and the dose-response training role of these endogenous hormones. Sports Med 2011; 41(2): 103-23.

21. Bosco C, Viru A. Testosterone and cortisol levels in blood of male sprinters, soccer players and cross-country skiers. Biol Sport 1998; 15(1): 3-8.

22. Broz P, Rajdl D, Novak J, Hromadka M, Racek J, Trefil L, Zeman V. High-sensitivity troponins after a standardized 2-hour treadmill run. J Med Biochem 2018; 37: 36472.

23. Lucía A, Chicharro JL, Pérez M, Serratosa L, Bandrés F, Legido JC. Reproductive function in male endurance athletes: sperm analysis and hormonal profile. J Appl Physiol (1985) 1996; 81(6): 2627-36.

24. Grandys M, Majerczak J, Zapart-Bukowska J, Kulpa J, Zoladz JA. Gonadal hormone status in highly trained sprinters and in untrained men. J Strength Cond Res 2011; 25(4): 1079-84.

25. Bhasin S, Taylor WE, Singh R, Artaza J, Sinha-Hikim I, Jasuja $R$, et al. The mechanisms of androgen effects on body composition: mesenchymal pluripotent cell as the target of androgen action. J Gerontol A Biol Sci Med Sci 2003; 58(12): M1103-10.

26. Bain J. The many faces of testosterone. Clin Interv Aging 2007; 2(4): 567-76.

27. Di Luigi L, Romanelli F, Sgrò P, Lenzi A. Andrological aspects of physical exercise and sport medicine. Endocrine 2012; 42: 278-84.

28. Hackney AC. Effects of endurance exercise on the reproductive system of men: the "exercise-hypogonadal male condition«. J Endocrinol Invest 2008; 31: 932-38.

29. Hagmar M, Hirschberg AL, Berglund L, Berglund $B$. Special attention to the weight-control strategies 
employed by Olympic athletes striving for leanness is required. Clin J Sport Med 2008; 18(1): 5-9.

30. Vingren JL, Kraemer WJ, Ratamess NA, Anderson JM, Volek JS, Maresh CM. Testosterone physiology in resistance exercise and training: the up-stream regulatory elements. Sports Med 2010; 40: 1037-53.

31. Hayes LD, Grace FM, Baker JS, Sculthorpe N. Exerciseinduced responses in salivary testosterone, cortisol, and their ratios in men: a meta-analysis. Sports Med 2015; 45(5): 713-26.

32. Sato J, lemitsu M, Katayama K, Ishida K, Kanao Y, Saito $M$. Responses of sex steroid hormones to different intensities of exercise in endurance athletes. Exp Physiol 2016; 101(1): 168-75.

33. Sgrò $P$, Romanelli F, Felici F, Sansone M, Bianchini S, Buzzachera CF, et al. Testosterone responses to standard- ized short-term sub-maximal and maximal endurance exercises: issues on the dynamic adaptive role of the hypothalamic-pituitary-testicular axis. J Endocrinol Invest 2014; 37(1): 13-24.

34. Jezová $D$, Vigas $M$, Tatár $P$, Kvetnanský $R$, Nazar $K$, Kaciuba-U cilko $\mathrm{H}$, et al. Plasma testosterone and catecholamine responses to physical exercise of different intensities in men. Eur J Appl Physiol Occup Physiol 1985; 54(1): 62-6.

35. Lac G, Berthon P. Changes in cortisol and testosterone levels and $\mathrm{T} / \mathrm{C}$ ratio during an endurance competition and recovery. J Sports Med Phys Fitness 2000; 40(2): 139-44.

36. Anderson T, Lane AR, Hackney AC. Cortisol and testosterone dynamics following exhaustive endurance exercise. Eur J Appl Physiol 2016; 116(8): 1503-9.

Received: April 6, 2018

Accepted: April 21, 2018 